\title{
Accidental Aspiration of a Finishing Bur: Clinical and Legal Aspects
} Aspiração Acidental de Broca de Acabamento: Aspectos Clínicos e Legais

Mário Marques Fernandes ${ }^{1}$, Antonio Carlos Andersson Westphalen ${ }^{2}$, Karen Ordovás ${ }^{3}$, Rachel Tinoco ${ }^{4}$, Fernanda Capurucho Horta Bouchardet $^{3}$, Eduardo Daruge Júnior ${ }^{4}$

\section{Resumo}

O objetivo deste trabalho foi apresentar um caso clínico de aspiração de broca protética de acabamento durante o tratamento odontológico e evidenciar aspectos clínicos, éticos e legais relacionados a esse tipo de acidente. Paciente do sexo masculino, 58 anos, durante um atendimento odontológico relatou que sentiu uma sensação de "coceira" na garganta. O atendimento foi interrompido e o mesmo encaminhado para atendimento hospitalar. Após radiografia e tomografia computadorizada do tórax foi constatada a aspiração acidental de uma broca de acabamento de restauração resinosa, removida com sucesso via broncoscopia. Cabe ao cirurgião-dentista conhecer e aplicar os meios necessários para prevenir a aspiração de objetos utilizados no tratamento, como a utilização do lençol de borracha ou amarrar objetos com o fio dental, bem como abordar as complicações decorrentes desse acidente. Dessa forma estará resguardado de possíveis demandas ético-judiciais por cumprir com suas responsabilidades profissionais.

Palavras chave: instrumentos odontológicos, complicações, Responsabilidade legal.

\section{Abstract}

The aim of this paper is to report a clinical case of prosthetic bur aspiration during dental procedure, and to evidence clinical, ethical and legal aspects related to this kind of accident. A male pacient, 58 years-old, during a dental procedure reported a sensation of itching in the throat. The service was discontinued and the patient was taken to hospital care. After imaging exam - radiography and computed tomography - it was diagnosed accidental aspiration of a finishing bur, which was successfully removed by bronchoscopy. The analysis of this case allows concluding that the dentist must know and apply the due means to prevent aspiration of foreign bodies during dental treatment, as the use of rubber dam or tying small objects with dental floss, as well as inform the patient about possible complications of this accident. This way the dentist will fulfill all professional responsibilities, and will be guarded from possible ethical issues.

Key works: dental instruments, complication, liability, legal.
${ }^{1}$ Departamento de Odontologia Legal, Associação Brasileira de Odontologia Seção Rio Grande do Sul, Porto Alegre, RS, Brasil.

${ }^{2}$ Department of Radiology and Biomedical Imaging, University of California, San Francisco, USA

3 Departamento de Odontologia, Faculdade de Odontologia da Pontifícia Universidade Católica de Minas Gerais, Belo Horizonte, MG, Brasil.

${ }^{4}$ Área de Odontologia Legal, Departamento de Odontologia Social, Faculdade de Odontologia de Piracicaba, Universidade de Campinas, Piracicaba, SP, Brasil.

Correspondência: Mário Marques Fernandes

Endereço: Rua Andrade Neves, 106 - $12^{\circ}$ andar, CEP 90010-210 - Porto Alegre RS, Brasil

Fone: (51) 32958031

E-mail: mario-mf@live.com

Data de Submissão: 30/08/2012

Data de Aceite: 23/05/2013

\section{Introduction}

Aspiration of a foreign body related to the performance of a dental procedure has a relatively low frequency, especially if compared with swallowing. Considering both kinds of accidents, the prosthetic dentistry is the dental specialty with the highest reported number of reported cases (TIWANA et al, 2004) ${ }^{7}$. Susini et al. ${ }^{6}(2007)$ have investigated the incidents recorded in France by two insurance companies over a period of 11 years and found 44 cases of aspiration of dental objects.

Whereas clinicians who work in prosthetic dentistry commonly handle small objects within the oral cavity, the transit of foreign bodies through the oropharynx may be considered an accident to some extent predictable and preventable. The concerns arising in this particular situation are initially of a clinical nature. Was the object ingested or aspirate? Should I try to find it or take the patient immediately to a hospital? Will a surgical intervention be needed? Furthermore, depending on the course of events, some legal issues may also arise. How far goes the clinician's responsibility? Who will bear the expenses of medical treatment? Can the dentist be sued by the patient due to the accident? (AL-RASHED, 2004; SAKELLARIDIS et al, 2008; WILCOX \& WILWERDING, 1999) ${ }^{1,4,8}$.

Given these and other questions, this paper aims to present a case of aspiration of a finishing bur during dental treatment, and highlight the clinical, ethical and legal issues related to this type of accident. 


\section{Case Report}

Male patient, 58 years, with an unremarkable past medical history, reported a sensation of itching in the throat during a dental treatment. The procedure was aborted and the patient was taken to a hospital with suspected passage of an object through the oropharynx. Arriving at the hospital, he was breathing and swallowing normally, adequately clearing secretions from the throat and spitting. Following radiological examination with chest x-ray and computed tomography scan, accidental aspiration of a finishing bur was diagnosed (Figure 1).

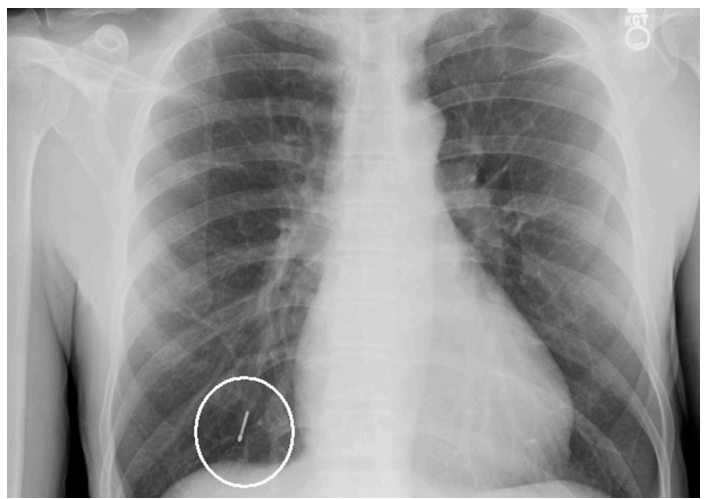

Fig. 1 - Thoracic radiograph taken in the accident day, showing the presence of a foreign body in posterior basal segment of the inferior lobus of the right lung (circle).

The staff opted for bronchoscopic removal, which was successfully performed with a wire-guided loop (Figures 2 and 3 ) under general anesthesia.

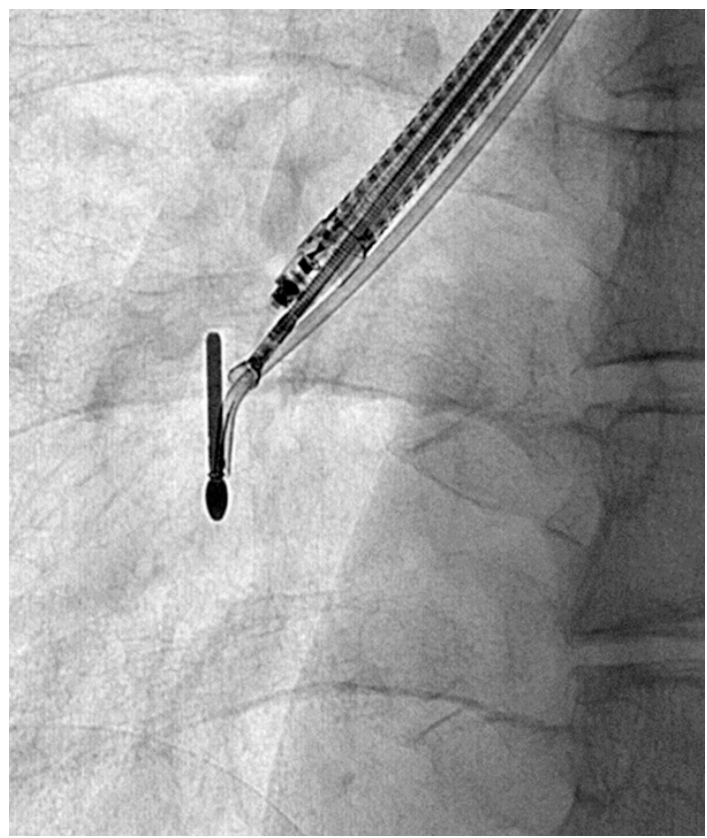

Fig. 2 - Fluoroscopic image showing the bur being captured by the wire-guided loop.

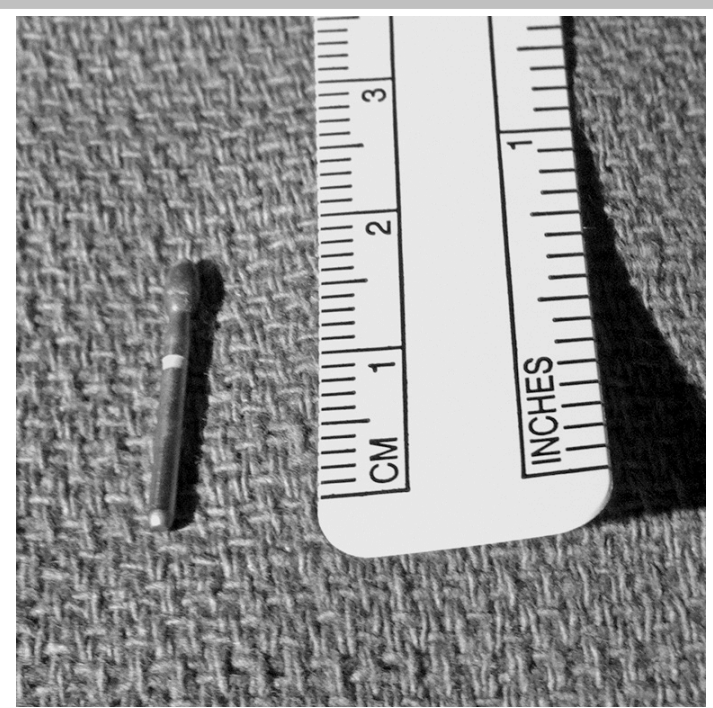

Fig. 3 - Characteristics and dimensions of the aspirated bur.

The patient was released without complications and remained asymptomatic. The patient was in dire economical conditions, had no insurance, and was referred to a non-profit organization that offers free legal support, in order to analyze the issue from the standpoint of professional liability.

\section{Discussion}

The aspiration or swallowing of any foreign bodies during dental treatment configures an accident that can be avoided in most cases with the use of physical barriers. In prosthodontics, the practice of tying prosthetic pieces with dental floss, including one-piece implants, can be a valuable alternative to prevent these accidents (NAKAJIMA \& SATO, 2004). In pre-prosthetic restorative procedures, the use of rubber dam is recommended not only to ensure an adequate therapeutic result, but also to avoid swallowing or aspiration of certain objects, such as burs, fragments of dental fillings, and bits of alloy and steel matrices (CAMERON et al, 1996; SUSINI et al, 2007; TIWANA et al, 2004) $)^{2,6,7}$.

Dental burs and finishing tips are among the most common types of swallowed objects, only behind the dental prosthesis (SUSINI et al, 2007) ${ }^{6}$. It is therefore recommended that, during restorative procedures, professionals always check if these parts are appropriately fixed to the equipment, and avoid replacing them near the mouth of the patient.

Another important aspect is the positioning of the patient's head during certain procedures. Facing the real possibility that certain objects (intact or fragmented) can accidently pass through the oropharynx, whenever is possible, the patient's head should be facing sideways, allowing dropped objects to lie on the sides of the mouth and not directly in the oropharynx (SILVA et al, 2011) . $^{5}$

If an accident happens and the object is not adequately visualized allowing for safe retrieval, the professional must observe the reaction of the patient while he/she talks and breathes. A foreign body, when aspirated, can significantly interfere with breathing and represent a medical emergency. In these cases, the professional may need to perform emergency maneuvers to remove the object, like the Heimlich maneuver, and must have an emergency number available to call for immediate assistance (ZITZMANN et al, 1999) ${ }^{9}$.

If the patient does not show changes that suggest aspiration, and is conscious and calm, the professional should inform him/her about the incident and end the dental procedure as soon as possible. The patient will need to be accompanied or referred to a medical 
service to undergo clinical and imaging evaluation to locate the foreign body. It is preferable to accompany the patient at all times, since the dentist will be able to describe the object (dimensions, shape and composition), helping the medical team to localize it and plan the appropriate management. If the dentist is not able to go to the hospital, information about the foreign body must be sent in writing, since not all dental materials are easily radiographically detectable (SILVA et al, 2011) . $^{5}$

Since some dental procedures have a greater risk of foreign body aspiration, it is important that the patients, or their legal representatives, receive previous explanations about the possible risks inherent to each procedure. This information should be provided both verbally and in writing, by a term of informed consent. The information provided should be adequate to each type of patient and each type of procedure. Thereby, the vocabulary used for younger patients should by compatible to their schooling; and anxious patients should receive more detailed information about the procedure. In general, for adults, it is recommended to use short sentences and lay terms (SILVA et al, 2011) ${ }^{5}$. A general rule is to use language that is understandable by anyone with 6th to 8th grade of schooling. Many of the current word processing computer programs have tools that inform the readability score of a text. Patients must also be adequately informed of post-treatment care, in particular when they have prosthetic elements in the oral cavity.

Patients who are adequately aware of potential problems related to the dental treatment usually share responsibility with the professional. The lack of information or basic measures to prevent aspiration of objects during dental treatment is often associated with judicial demands. In these situations, even if the dentist is found not guilty, there is always physical, emotional and professional stress. Thus, it is essential that health professionals follow the steps recommended in the dental literature while planning, performing and

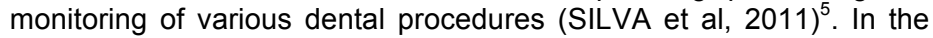
case shown, the dentist reacted appropriately by informing the patient about the situation and referring him to medical care, which led to uneventful retrieval of the bur.

It is duty of the dentist to know and apply the means necessary to prevent objects aspiration during dental treatment. This way, the dentist will fulfill his/her professional responsibilities, and will be guarded from possible ethical and legal issues.

\section{Acknowledgements}

The authors would like to thank Dr. Jeffrey A. Golden, Professor of Clinical Medicine, and Dr. John Greenland, Clinical Fellow, from the University of California San Francisco Department of Medicine for the bronchoscopic images.

\section{References}

AL-RASHED, M.A. A method to prevent aspiration or ingestion of cast post and core restorations. J. Prosthet. Dent., St. Louis, v. 91, n. 5, p. 501-502, 2004.

CAMERON, S.M.; WHITLOCK, W.L.; TABOR, M.S. Foreign body aspiration in dentistry: a review. J. Am. Dent. Assoc., Chicago, v. 127, n. 8, p. 1224-1229, 1996.

NAKAJIMA, M.; SATO, Y. A method for preventing aspiration or ingestion of fixed restorations. J. Prosthet. Dent., St. Louis, v. 92, n. 3, p.303, 2004.

SAKELLARIDIS, T.; KOULAXOUZIDIS, G.; PANAGIOTOU, I.; KIGKA, C.; PAPAMICHALIS, G.; ANTYPAS, G. Aspiration of fixed dental prosthesis following maxillofacial trauma. Emerg. Med. J., London, v. 25, n. 3, p. 143, 2008.

SILVA, R.F.; MARTINS, E.C.; PRADO, F.B.; et al. Endoscopic removal of an endodontc file accidentaly swallowed: clinical and legal approaches. Aust. Endod. j., Melbourne, v. 37, p. 127-134, 2011.

SUSINI, G.; POMMEL, L.; CAMPS, J. Accidental ingestion and aspiration of root canal instruments and other dental foreign bodies in a French population. Int. Endod. J., Oxford, v. 40, n. 8, p. 585-589, 2007.

TIWANA, K.K.; MORTON, T.; TIWANA, P.S. Aspiration and ingestion in dental practice: a 10-year institutional review. J. Am. Dent. Assoc., Chicago, v.135, n. 9, p.1287-1291, 2004.

WILCOX, C.W.; WILWERDING, T.M. Aid for preventing aspiration/ingestion of single crowns. J. Prosthet. Dent., St. Louis, v. 81, n. 3, p. 370-371, 1999.

ZITZMANN, N.U.; ELSASSER, S.; FRIED, R.; et al. Foreign body ingestion and aspiration. Oral. Surg. Oral. Med. Oral. Pathol. Oral. Radiol. Endod., St. Louis, v. 88, n. 6, p. 657-660, 1999. 